\title{
DIGITAL INFRASTRUCTURES AND URBAN GOVERNANCE
}

The urban built environment is underpinned by an increasingly complex digital infrastructure, which is posing a variety of unpredictable and unprecedented challenges for urban governance. The paper outlines the key strands of digital infrastructures which underpin the urban polity, including the role of global technology providers in shaping the urban governance agenda around digital policy; and the emergence of smart city strategies. The paper is illustrated using empirical examples drawn from Australian digital infrastructure development, with reference to the international landscape of 'smart city' developments. It argues that there is a significant mismatch between the often small scale, bounded capabilities of municipal government, and the actively large-scale operations of technology firms. 


\section{INTRODUCTION}

The digital foundations of the modern city are becoming an increasingly visible part of everyday urban life. Urban infrastructure is being 'instrumented' by sensor technologies, allowing information processing to be diffused into the material spaces of cities. There is growing recognition that 'public sector information' (PSI) and public urban data represents an increasingly strategic, and potentially monetisable, asset. A recent OECD paper estimated a value of PSI data at EUR 32 billion for the European market alone (OECD 2014: 4), resulting from new organisational and management approaches or significantly improving existing practices. Such benefits can be obtained from weather forecasts, traffic management, crime statistics, improved transparency of government functions (e.g. procurement) and educational and cultural knowledge for the wider population (OECD 2014). More recently, growing attention towards the use of IoT ('internet of things) has also highlighted opportunities for smart infrastructure services in cities, driven by distributed sensors delivering real-time performance data and allowing improved monitoring of urban systems.

This paper examines a set of governance challenges associated with recent digital infrastructure investments and strategies, reflecting a broader shift away from vertical, often government-controlled integration, to environments involving a mix of multiple public, private and quasi-private entities that manage and govern urban infrastructural systems (Alizadeh, Sipe and Dodson 2014). Accompanying these shifts, the governance of digital infrastructures is extending from a narrow focus on the technical infrastructure of pipes and cables that deliver digital communications to Australian cities and regions, to include concerns around the management, use, access and distribution of data to support decision making by city authorities under the rubric of 'smart city' policies.

The paper addresses two recent approaches to Australian public investments in digital infrastructure. The first relates to the Federal Government investment in national broadband infrastructure, in which digital infrastructure was framed more conventionally as an engineering problem, its assets promoted as a means to supporting knowledge-based economic development goals across Australian cities and regions. This approach saw public investment in digital infrastructure justified as 
a means to attracting global capital and build digital economy capabilities, thus confirming a more traditional 'urban entrepreneurial' approach-whether at national, regional or urban scale. The second, more recent approach has shifted the focus away from the physical dimensions of broadband technology as an enabling infrastructure of the digital economy, towards emphasis on the role of government as enabler and facilitator of data-driven services.

\section{The political economy of digital infrastructure}

At times, Australian public discourse on digital infrastructures is reduced to the efficiency and cost effectiveness of various engineering and procurement processes: how best to deliver networks of cable, fibre and telecommunications masts; datacenters; and front end devices, apparently neutral assets that can be manipulated and designed to achieve desired strategic outcomes (Beckert 1999; Child 1997; Broadbent and Weill 1997). Another view of digital infrastructure is grounded in systems and complexity theory, which argues that to understand digital infrastructure requires understanding the relationship between the technological and social elements of such systems (Tilson et al. 2010a; Vaast and Walsham 2009). In digital infrastructure terms these social elements include the changing industry, regulatory, and market structures as well as the wide ranging effects on citizens' lives, work, and interactions that have been rapidly advanced the most recent wave of digitization .As Tilson et al. describe "a rapid divergence is emerging in how service creation, distribution, and use occurs, which, paradoxically, is built upon the convergence around the bit” (Tilson et al, 2010b).

A powerful critique of how infrastructure is currently developed globally has emerged, however. The 'splintering urbanism' approach advanced by Graham and Marvin (2001) has been particularly influential here. It charted a worldwide unbundling of infrastructure networks, particularly around the privatization and split ownership of information and communication technologies, driven largely by a neoliberal agenda of less state involvement in asset ownership and management. As the smart cities agenda has developed, this has been given a clear profile in terms of public policy. Under post-industrial 'new economy' growth frameworks, the economic competitiveness of cities has been largely understood through the lens of 'urban entrepreneurialism' (Harvey, 1989). In this context, attempts to understand 
the significance of the 'digital city' have involved the hybridization of urban policy between incentivizing the location and retention of technology firms and employees, on the one hand, and delivering digitized, and hence 'smart', public services (see for example Hollands 2008; Blakely \& Bradshaw, 2002; Alizadeh, Sipe and Dodson 2014; Wiig 2015). This has led to a blurring of the role of public and private actors in policy formation and service delivery, as well as creating a new set of policy challenges that public discourse has little grasp on. As Rob Kitchin has argued:

"Smart city advocates imagine themselves as creating technologies, techniques and visions that are scientific, objective, commonsensical and apolitical. In general, there is little critical reflection on the wider implications of technologically rooted entrepreneurial urban development, or the consequences of networked urbanism, for city administrations and citizens. Left untouched are issues such as panoptic surveillance, technocratic and corporate forms of governance, technological lock-ins, profiling and social sorting, anticipatory governance, control creep, the hollowing out of state provided services, widening inequalities and dispossession of land and livelihoods (especially on green field sites).” (p.2).

\section{Building digital infrastructure for Australian cities}

In Australia in recent years, digital infrastructure investment has been given a prominent role. From 2009 until 2013, digital infrastructure investment was explicitly championed by Government as a core 'nation building' exercise and fundamental to Australia's future growth. This began with the announcement in April 2009 by the Federal Labour Government of a $\$ 44$ billion National Broadband Network initiative (NBN). The intention of the NBN was to deliver terrestrial fibre network coverage for 93 per cent of Australian premises by the end of 2020, with the remaining 7 per cent served by fixed wireless and satellite coverage (NBN Co. Ltd., 2010). Had it progressed in its planned form, the NBN would have represented the largest single infrastructure project undertaken in Australia's history (see Alizadeh, Sipe and Dodson 2014). 
Following announcement of the NBN, the Federal Government supported a range of initiatives to promote access to and use of broadband infrastructure by Australian communities. In May 2011 it released the \#au20 National Digital Economy Strategy, with an aim that by 2020, Australia will be among the world's leading digital economies. This was accompanied by a set of key 'Digital Economy Goals' that focused on the following areas: improving online participation by Australian households; promoting online engagement by Australian businesses and not-forprofit organisations; smart management of environment and infrastructure; improved health and aged care; expanded online education; increased teleworking; improved online government service delivery and engagement; and greater digital engagement in Regional Australia (see DBDCE 2011).

Federal Government investment in next-generation broadband infrastructure was also accompanied by a significant number of programs to enable communities based outside metropolitan centres to maximise the benefits of this digital infrastructure investment. The creation of the $\$ 1.4$ bn Regional Development Australia (RDA) fund in 2011 saw investment in a raft of digital economy strategies that outlined how NBN infrastructure could be used to support local economic development goals and priorities, largely by increasing the use of digital services by local businesses and organisations. As one such strategy outlined: "The advent of the National Broadband Network (NBN) and the potential of other digital technologies present new opportunities for economic, social and environmental development in the region" (RDA Peel, 2012). The RDA Northern Rivers Digital Economy Strategy for Businesses also focused on "how high-speed broadband can contribute towards growth of existing private sector businesses, together with opportunities for 'new' technology firms to establish themselves in the region" (2013).

The table below outlines a set of examples of RDA-sponsored digital strategies commissioned between 2011 and 2013 and the key priorities of each.

\begin{tabular}{|l|l|l|}
\hline RDA & Digital Strategy, year & Priority areas \\
\hline Geelong, Victoria & $\begin{array}{l}\text { G21 Digital Strategy (2012) } \\
\text { http://www.ictgeelong.com.au/ind } \\
\text { ex.php/key-activity/g21-digital- } \\
\text { strategy }\end{array}$ & $\begin{array}{l}\text { Increase business uptake of digital } \\
\text { solutions that enhance productivity and } \\
\text { profit. } \\
\text { Improve G21 region's connectivity for } \\
\text { residents, students, travellers and } \\
\text { business people on the move throughout } \\
\text { the city. }\end{array}$ \\
\hline
\end{tabular}




\begin{tabular}{|c|c|c|}
\hline & & $\begin{array}{l}\text { Build the capacity of G21 region's digital } \\
\text { industries. } \\
\text { Promote G } 21 \text { region's wealth of digital } \\
\text { capability. }\end{array}$ \\
\hline Hume Victoria & $\begin{array}{l}\text { Digital Hume: A digital strategy for } \\
\text { a smart region (2013) } \\
\text { See: } \\
\text { http://www.rdv.vic.gov.au/regional- } \\
\text { development-australia/hume/ict/ict- } \\
\text { strategy-development }\end{array}$ & $\begin{array}{l}\text { Maximising the impact of the NBN } \\
\text { Striving to get all online by } 2017 \\
\text { Working towards transforming of } \\
\text { public services } \\
\text { Encouraging digital enabled businesses } \\
\text { Marketing Digital Hume }\end{array}$ \\
\hline $\begin{array}{l}\text { RDA Murraylands, } \\
\text { Victoria }\end{array}$ & $\begin{array}{l}\text { The Digital World: An opportunity } \\
\text { to connect (2012) } \\
\text { http://www.rdamr.org.au/fileadmin/ } \\
\text { user_upload/Riverland/documents/R } \\
\text { DAMR_ } \\
\text { Digital_Strategy_Document_2014_ } \\
\text { Final.pdf }\end{array}$ & $\begin{array}{l}\text { Encourage and promote investment } \\
\text { attraction and the diversification of } \\
\text { Industry within the region in an } \\
\text { endeavour for Economic Growth, } \\
\text { Population Growth and the building of } \\
\text { capacity and capability within the } \\
\text { community. }\end{array}$ \\
\hline $\begin{array}{l}\text { Peel RDA, } \\
\text { Western Australia }\end{array}$ & $\begin{array}{l}\text { Building the Peel's digital future } \\
\text { (2012) } \\
\text { http://www.rdapeel.org.au/wp- } \\
\text { content/uploads/2015/05/Peel- } \\
\text { Digital-Futures-Strategy-FINAL.pdf }\end{array}$ & $\begin{array}{l}\text { The diverse economic base, enabled by } \\
\text { technology, will support an improved } \\
\text { level of employment sustainability and a } \\
\text { greater range of employment } \\
\text { occupations. Professionals, freelancers } \\
\text { and members of the "creative class" will } \\
\text { be attracted to work and live in the } \\
\text { region, supported by good access to } \\
\text { digital technologies and services. }\end{array}$ \\
\hline $\begin{array}{l}\text { RDA Northern } \\
\text { Inland }\end{array}$ & $\begin{array}{l}\text { RDANI Digital Economy Strategy } \\
\text { (2013) } \\
\text { http://www.rdani.org.au/projects/dig } \\
\text { ital-economy-strategy.php }\end{array}$ & $\begin{array}{l}\text { Focuses on how high-speed broadband } \\
\text { can contribute towards growth of existing } \\
\text { private sector businesses, together with } \\
\text { opportunities for 'new' technology firms } \\
\text { to establish themselves in the region. }\end{array}$ \\
\hline $\begin{array}{l}\text { Northern Rivers } \\
\text { RDA, NSW }\end{array}$ & $\begin{array}{l}\text { Northern Rivers Digital Economy } \\
\text { Strategy (2013) } \\
\text { http://rdanorthernrivers.org.au/down } \\
\text { load/industry_and_economic_devel } \\
\text { opment/digital- } \\
\text { economy/NR\%20Digital\%20Econo } \\
\text { my\%20Strategy\%20WEB.pdf }\end{array}$ & $\begin{array}{l}\text { To improve lives, businesses and } \\
\text { communities in the Northern Rivers the } \\
\text { strategy focuses on: } \\
\text {-harnessing digital technologies today to } \\
\text { provide better education, enhance digital } \\
\text { literacy, increase access to Government } \\
\text { services, and improve the health of the } \\
\text { community; } \\
\text {-optimising the use of digital } \\
\text { technologies to build more profitable } \\
\text { businesses and ensure their long term } \\
\text { future, while respecting and maintaining } \\
\text { the quality of our natural environment; } \\
\text { and } \\
\text {-using digital technology to allow } \\
\text { improved collaboration between diverse } \\
\text { communities to maintain and enhance the } \\
\text { unique fabric of the region. }\end{array}$ \\
\hline
\end{tabular}




\begin{tabular}{|l|l|l|}
\hline $\begin{array}{l}\text { Mid North Coast } \\
\text { RDA, NSW }\end{array}$ & $\begin{array}{l}\text { Making the Connections, Filling the } \\
\text { Gaps (2011) } \\
\text { http://www.rdamnc.org.au/wp- } \\
\text { content/uploads/mid-north-coast- } \\
\text { digital-stategy-final-lr.pdf }\end{array}$ & $\begin{array}{l}\text { The Mid North Coast region has a game- } \\
\text { changing opportunity } \bullet \text { to raise GDP } \\
\text { change market perceptions of the area } \\
\text { transform public services } \bullet \text { up-skill and } \\
\text { strengthen local communities; and } \\
\text { reinforce an emerging digital economy }\end{array}$ \\
\end{tabular}

Under the federal Digital Economy Strategy released in 2011 by the former Department of Broadband, Communications, and Digital Economy (DBCDE), greater investment was advocated to support local businesses in maximising the economic benefits of digital infrastructure investment for Australian communities (DBDCE 2011: 34). A Government Business Enterprise (GBE), NBN Co Limited, was established to manage the roll-out of the infrastructure, with a view to building over the long-term a more competitive structure for Australian telecommunications. In particular, the model of NBN Co facilitated 'structural separation' between the 'backbone network' of wholesale service provision, and retail services delivered by internet service providers (ISPs) to customers. This structural separation was a long term goal of Australian telecommunications policy, designed to address competition issues surrounding the former government-owned telecommunications provider Telstra, whose dominant position in the marketplace had been the subject of frequent reviews and hearings by Australia's competition watchdog (see Nicholls, 2014).

According to Alizadeh, Sipe and Dodson (2014), the NBN investment represented a major advance in the quality of information technology infrastructure in Australia. Rather than a patchwork of private, globalised and networked infrastructure providers, here was a ubiquitous, vertically and horizontally integrated and organized, national megaproject. However, following the 2013 election of a new Coalition Government, Federal Government policy on the NBN was significantly revised, based on the argument by incoming Coalition Government that the former Labour Government had poorly managed the set up and operation of the NBN Co. The outcome of the new policy has indeed resulted in a patchwork of different commercial providers and scaling back of direct government investment-more akin to the 'splintering' model of contemporary infrastructure investments. 
Under the Coalition policy, investment was scaled back from $\$ 44 \mathrm{bn}$ to $\$ 29.5$ bn (this has now risen back to $\$ 46-56 \mathrm{bn}$ ), and the design of the network refocused around 'fibre to the node' (FTTN) rather than 'fibre to the premises' (FTTP). An independent review of NBN Co also found that NBN Co lacked "deep internal experience in complex infrastructure, construction projects and project management" (Commonwealth of Australia 2013: 13). The redesign of the network around FTTN represented a significant reduction in network capability, with the Coalition Government's FTTN design involving a 'multi-technology mix' (MTM) that was more reliant on an existing legacy copper wire network rather than a new fibre-optic network. As technology commentator Paul Budde commented, this saw Australia increase investment in its existing copper cables just as the rest of the world began to move away from copper to fibre (Budde 2016).

In December 2014, the Federal Government announced that that NBN Co would meet its roll-out schedule partly by acquiring existing HFC cable infrastructure owned by telecommunications providers Telstra and Optus-SingTel; the deal with Telstra was at a cost of $\$ 11$ bn (see Telstra 2014). In April 2016 Telstra was also awarded a $\$ 1$.bn contract to manage the design, construction management and upgrades to the HFC cable that had been previously sold to the NBN Co in 2014. This deal has raised concerns from Australia's competition regulator about Telstra's competitive advantage in the provision of digital infrastructure to Australian homes (ABC News, 2016).

New telecommunications policy at the Federal level, promoting an MTM model in the provision of NBN infrastructure, has impacted the implementation of those local digital strategies previously funded to maximise the benefits of next-generation broadband. Under Coalition policy between 2013 and 2015, the narrative around the NBN shifted away from that of an enabling infrastructure facilitating 'nation building', to one requiring what Peck, Theodore and Brenner (2012: 269) have described as "market-disciplinary regulatory restructuring". NBN Co, a creation of the former Labor Government, was framed by the Coalition as inexperienced in infrastructure management, with a succession of former CEOs of international telecommunications providers installed to 'fix' the organisation (see Commonwealth of Australia 2015). No additional funding has since been administered through RDA 
for further digital economy strategies to promote 'take-up' of NBN broadband infrastructure.

The different policy positions adopted by successive Australian Governments do help underscore just how bound up infrastructure investment programs can be to the normative aspirations of their funders (Graham and Marvin 2001). Under Labor, the NBN was a focal feature of the Australian Government's policy platform and was accompanied by high expectations about its ability to resolve multiple policy challenges relating to economic productivity and social connectedness (Alizadeh, Sipe and Dodson 2014). For the Coalition Government, the NBN was positioned as a victim of poor management, requiring the corrective of effective economic management to ensure cost-reductions for consumers and more efficient organisational business practices.

\section{From enabling to instrumenting: the rise of the smart city}

Globally, the development of 'smart city' policies has seen another shift in the framing of digital infrastructure. Within smart cities, public investment in digital infrastructure is seen as central platform for evaluating the performance and management of cities and governments (see for example Arup 2014). This shift suggests greater attention is needed to address governance implications of digital infrastructure in an age of smart cities. As Luque-Ayala and Marvin (2015: 8) have argued:

"An emerging set of detailed conceptual work is needed to illustrate how smart technologies - data analysis, software systems, networked infrastructure and new digital systems such as sophisticated control and pricing technologies - are used to more intensively unbundle and rebundle users, space, services and networks. Further conceptual and empirical work is needed to examine what political rationalities are embedded within such responses, and which stakeholders are excluded from the future 'smart city'."

The past five years have seen widespread uptake of smart city strategies by cities around the world, provoking greater attention towards the governance opportunities 
associated with cities that are 'run on information'. This has been manifest not only in the operational activities of city governments but also in a shift in the fundamental role and purpose of city governance in the information age. Notably, specialist consultants are driving forward this agenda. As the engineering and planning firm Arup argued in a 2010 white paper, "the smart city is so different in essence to the 20th century city that the governance models and organisational frameworks themselves must evolve" (Arup 2010). Arup has been upbeat about the potential for governance improvements resulting from smart city-led instrumentation, which, it argues "allow us to rewire governments by design, transforming the way they work internally and together with outside partners and citizens" (p.32). Indeed one of the identified benefits of smart city technologies is the 'reinvention of governance' (Arup 2014).

Leveraging advances in data development, aggregation and engagement, many governments are deploying the 'city wide digital strategy' as a governance intervention to ensure their jurisdictions properly capitalise on the opportunities around data-driven governance (Barns 2016). These strategies can be seen as distinct from previous generations of digital economy strategy or 'digital era governance' (Dunleavy 2013), in that they are more focused on implementing data-driven decision making tools as integral to the performance of governing itself-not just to the role of government in supporting or enabling particular industry sectors. In cities such as New York, data-driven analytics tools and platforms are used to improve internal efficiencies and deliver better services to citizens (NYC 2011). More widely, open data platforms are prioritized by city governments as strategic engagement tools to allow government data to be released in machine-readable formats, adopted by entrepreneurs and software developers to deliver new services and platforms to citizens.

Through these emergent policy models, we are seeing the conditions of access to and use of public service information (PSI), along with the particular framing of datadriven discovery methods, becoming increasingly integral to questions of policy formulation and everyday urban governance. Though governments are generally considered to be the custodians of public service information, they don't always possess the governance capabilities to design and implement new systems and 
processes for integrated, large-scale data harvesting and processing implied by urban big data.

In the global context, we are seeing a new set of private actors and capabilities becoming increasingly embedded within urban policy and governance settings. These firms are often scaled globally, which contrasts sharply with the localized nature of urban government. These actors include the 'supplier' side of traditional physical infrastructure components, which tend to be large private companies that are either contracted by government to implement networks of optical fibre, or who invest themselves in these networks in order to capture market share. For example in the UK British Telecom (BT) have a universal service obligation to provide telecoms infrastructure, but private companies like Virgin Media have opted to invest in their own FTTH services rather than using BT's infrastructure.

Some cities have set up their own public companies to provide physical infrastructure. For example in 1994 Stockholm City Council created 'Stokab’ which they still own (http://stokab.se). The goal of the company has been to "build a competition-neutral infrastructure capable of meeting future communication needs, spur economic activity, diversity and freedom of choice, as well as minimising disruption to the city's streets." (www.Stokab.se/In-English). Other cities also own their own cable networks and use these assets for local development, such as Bristol's fibre network being used for development of the Temple Meads Business district.

Building on top of these services many large global tech companies such as IBM, Cisco, Siemens, Oracle (etc.) have been selling the concept of "city operating systems", whereby city services are managed and controlled through centralised software located and operations centres in the city (Marvin et al 2015, Luque and Marvin 2015, McNeill 2015). Although this concept has been met with much criticism (such as Vanolo 2014) these operations centres have been rolled out in some cities, perhaps most famously in Rio de Janeiro.

Given the rapid changes in technological platforms in recent years, we can also identify a diverse set of actors that build upon the foundational digital infrastructure in cites for a variety of purposes that are in some cases severely disrupting the operations, markets and experience of cities. We see global corporations such as Uber and Airbnb able to scale rapidly based on new digitally-enabled service models that 
require vastly reduced investment in capital assets as compared with their competitors. Smaller tech companies and start-ups are also capitalising on digital infrastructure systems to create new services for citizens. These include the innovations in transport services such as CityMapper, which was set up after London created its open data platform called the 'London Datastore'. Companies with more social intentions such as Ushahidi ${ }^{1}$ who crowdsource citizen information during extreme events and MySociety ${ }^{2}$ who have created a variety of services to support engagement between citizens and government are changing the urban experience by empowering citizen voices through technology.

In order to escape the binary city-individual limits and the 'deterritorialised' trap of the smart city, it is useful to follow on Keil and Mahon's (2009) effort to start from a critical sense of scale, thinking digital infrastructure in the richness of its complex spatial inter-relationships. In fact, the development of networked urban infrastructures can itself retrofit the very boundaries of 'scale' and scalar perceptions, as digital innovations tinker with the "focal setting at which spatial boundaries are defined” (Agnew 1997: 100). The challenge of studying the politics of digital infrastructure, then, is also one of understanding the variety of, and contrasts between, urban imaginaries at play at the very same time by a diverse set of private sector led actors (Gibbs et al. 2013).

\section{Governance implications for cities}

\section{Challenge 1: Data driven urban governance and strategy}

"Open data, or the release of data in re-usable and machine-readable formats, has become an increasingly vibrant field for data scientists and entrepreneurs who see opportunities to combine public or government data with other geographical information as a means to deliver new data-driven services and platforms. Where it originally advanced in close alignment with the "open government" movement on one hand, in promoting greater citizen engagement and transparency of public institutions, and the open source

\footnotetext{
${ }^{1}$ Ushaidi's http://www.ushahidi.com/

2 https://www.mysociety.org/
} 
software movement on the other, the recent proliferation of open data platforms can in one sense disrupt the notion that smart city policies are necessarily "vendor-driven"- that is, designed to reflect the business strategies of particular rent-seeking firms. Put bluntly, if smart city policies are simply reflections of decisions around which vendor-backed software to buy, why are so many cities adopting open standards as part of their smart city policies?” (Barns 2016 p.555).

At first sight, the promises of the real-time city, where use of real-time data reveals in more fine-grained detail the complex systems of interlocking and multi-scalar networks of transportation, logistics, e-commerce transactions and the like which together make up the general urban condition, are premised largely on a relatively simplistic causal relationship between access to data and better urban decision making. But in reality not only is access to integrated real-time data sets anything but simple, for many governments, administrative boundaries for intervention do not map neatly over the territories to which accessible data-holdings may apply.

Furthermore, the relative limiting of the governance capabilities of successive local and State-based agencies through privatization agendas (Gleeson et al 2004, Dodson 2009), has left many local governments with a more limited capacity to access and make use of large quantities of urban data, now held by private utilities. Major Australian cities are constituted by a patchwork of local government areas (LGAs) overlaid with State and Federal jurisdictions responsible for areas such transport, education, and health. The exception here is Brisbane City Council, the largest local government administration in Australia. Its scale has meant that Brisbane City has also taken on a major transport infrastructure planning role, which in some aspects rivals that of the State (Dodson 2009, p.117). By contrast, the Sydney metropolitan region, for example, is comprised of 41 LGAs and 6 regional areas. The NSW Government, with responsibilities for both public transport and land use planning, has introduced successive Metro Strategies, recognized as relatively weak governance instruments comparative to State-based planning and infrastructure programs. No single agency has an integrated spatial authority over separate urban infrastructures and patterns of urban mobility, the basis from which many integrated real-time views of the city might be made possible. 
Australian Governments at Federal, State and local levels are implementing a range of digital transformation initiatives directed at improving business and operational processes through use of data-driven tools. These initiatives range in their scale and impact. At the Federal level, a newly created 'Digital Transformation Office' (DTO) leads digital transformation across Federal agencies through initiatives such as dashboards and data-driven, customer-centric apps and platforms. While successive Australian Governments have actively pursued a range of digital economy strategies and programs, the creation of the DTO is the first major attempt to systematically introduce data-driven transformation across agencies.

At the State government level, governments are adopting agent-based data models are used to promote more integrated approaches to land-use planning and infrastructure investment (see SMART, 2012). The majority of State Governments are trialing the 'government as platform' model, releasing Open Data in machinereadable formats for improved services provision via platforms such as data.gov.au and related sites.

As Dodson (2009) has argued, over the past decade an 'infrastructure turn' across Australian cities has resulted in a concomitant shift in focus away from strategic spatial planning. Along with a weakening of the influence of planning agencies in shaping metropolitan policy, has been growth in the influence of infrastructure departments and ad hoc engineering project 'investigations' (Dodson 2009, 112). The relative weakness of strategic spatial planning practices can be seen to act as a deterrent to any one agency or level of government adopting the scale of smart city strategy or policy evident elsewhere in the landscape of smart city international development. Consequently, the application of data analytics is often confined to single agencies such as transport infrastructure departments, without coherent or real-time application across different infrastructure and land use programs. In NSW, this lack of metro-scale governance has been the subject of increasing criticism from business groups such as the Committee for Sydney, which argues that many of Sydney's most urgent development challenges require not only a metro strategy but a metropolitan governing agency.

The patchwork of governance that is a feature of Australian cities is far removed from the 'control room' model of the smart city that foregrounds the use of real-time 
urban data as a means for integrated and sophisticated analyses of urban behavior and planning effective urban management outcomes (Alizadeh and Shearer 2015). It is to this strategic scale of the metropolitan region that smart city approaches to integrated data analytics are primarily directed. According to Bettencourt (2013: 1), "the primary role of big data in cities is to facilitate information flows and mechanisms of learning and coordination by heterogeneous individuals." It may be that the global interest and pursuit of integrated data analytics may result in a refocusing of attention towards the importance of integrated spatial planning as a strategic practice - whereby the effectiveness of city-wide data analytics clearly depends on governance arrangements that promote effective management and coordination within urban regions and across jurisdictions.

\section{Challenge 2: corporate 'capture' and the marketing of the smart city}

For Australian cities, investment in strategic frameworks to support smart cityinitiatives has been slow relative to other advanced economies. As one commentator put it, "Australian governments are in no hurry to become smart" (Hall 2014). Of the major metropolitan cities, the City of Brisbane was the only government to have adopted a 'whole of government' digital strategy that includes smart city targets (Digital Brisbane 2012). However, a new Prime Minister whose personal fortunes have been closely tied to the technology sector has seen a shift in public support for smart city development, with rapid acceleration in smart city policy during the first months of 2016. In April 2016, the Federal Government announced its Smart Cities Plan, while a number of local government authorities, including Newcastle City Council and Parramatta City Council, are proceeding with smart city strategies and policies.

In May 2015, IBM announced the selection of the City of Melbourne as a recipient of one of the latest awards in IBM's Smarter Cities Challenge Grant awards, one of sixteen recipients from one hundred applicants. The Challenge, wrapped within IBM's Corporate Service Corps, is a pro bono 'philanthropical' division of the corporation that dispatches IBM employees to projects submitted by cities around the world. As part of this process IBM employees spend three weeks living in each municipality, "giving them a real feel for the tex ture of local daily life." The winning applicants are expected to show "that they are ready to match IBM's investment with 
its own commitment of time and talent." IBM defined the role of the visits as to "outline a range of concrete strategies designed to help make cities healthier, safer, smarter, more prosperous, and attractive to current and prospective residents and businesses." (IBM 2012). The value of each grant is nominally ascribed as US $\$ 400,000$. Every year since its launch, the company has engaged more than 20 municipal governments, from Birmingham in the UK, to Cheongju in South Korea, and has worked on a range of city-specific urban policy issues, the lessons from which could be scaled globally.

At first glance, the use of 'philanthropic' modes of engagement with local governments - who are usually receptive to these possibilities given chronically strained recurrent budgets - is a normative good. The projects are also strong 'headline' initiatives that councils can publicise, promising significant observable changes in the ease and costs of everyday life things, from cheaper water provision to reducing congestion through intelligent traffic lights. However, the harder side of the relationship between city governments and the major technology corporations comes in the procurement of major IT and software platform contracts. These contractual relationships are often a complex and highly confidential process, and occasionally come unstuck.

A key example in the Australian context is the Queensland Health Payroll System Commission of Inquiry (2013). In this case, the Queensland Government contracted with IBM to deliver a payroll system for its public sector health employees. The Inquiry revealed that IBM had been selected over its main competitor, Accenture, on the basis of price, but the system changeover had failed in a very high profile way, with many frontline staff not being paid on time. These procurement issues continue to be played out across Australian local and state governments. For reasons of both complexity and cost, it appears that many city governments have been reluctant to invest in the full set of smart city options that corporations are offering to them. Commenting on a deal between Adelaide City Council and Cisco, the city's Chief Executive was quoted: "I would not want Adelaide to be at the bleeding edge of technology but I am keen to progress this. We are quite happy for a company like Cisco to come and work with us but I will reserve my judgment” (in Hall 2014). 
Such caution seems to reflect a view that we are still in an experimental phase of smart city technology: major firms such as IBM are still to convincingly display a profit on their smart city products, and despite their high profile pilot projects, it is not clear that they will find it easy to standardize a common product or strategy on a global scale (McNeill 2015). Australia will be an interesting test of this, given its relatively small municipalities.

\section{Conclusions}

The politics of the digital city are structured around a highly differentiated governance landscape. As we have shown, privatization of major core urban assets, from energy to rail and telecommunications has also ensured data accessibility remains more limited. In turn, this process has limited the scale and volume of data, related to contemporary urban flows (energy, telecommunications, and in some instances rail) that is actually accessible by public agencies for the purposes of integrated, spatially coordinated urban management. In many ways, this continues to follow the 'splintering' logic described by Graham and Marvin (2001) where premium network infrastructures are made available on a user pays model. On the other hand, the relative fluidity of datasets, which lacks the huge sunk costs of 'hard' infrastructure, makes this a far more elusive and complex object of governance. Making open data available brings its own political challenges, and as we noted above often hybridizes different policy elements: "Through the open data movement the conditions of good governance are also linked to the success of digital entrepreneurialism, the vibrancy of a local tech sector, and the successful integration of public data assets into proprietary software services.' (Barns 2016 p.566). Moreover, it means that the elected bodies associated with governing cities must have skills in negotiating with a wide range of actors, from multinational firms like Uber, Cisco and IBM, national technology giants like Telstra, and a wide range of start-ups and SMEs responding to procurement opportunities.

The question of public data, and how it is used, has also been an important field of inquiry, and one that continues to evolve. From a political economy perspective, it is important to move into a finer-grained analysis of how data is deployed, monetized, and stored than has often been the case. And so, as one of us has argued elsewhere, 
"Where open data programs require the publication of highly localized data sources in machine-readable formats, and do so to facilitate new marketplaces for software entrepreneurship using public data assets, they become an important mechanism for the introduction of entrepreneurial governance by code. Perhaps more so than promoting government accountability and citizen-oriented engagement, this reconstitution of the role of government may be the greatest legacy of open data programs." (Barns 2016, p.556).

These challenges demand more extended considerations on the multi-level governance of the 'smart city'. As we have discussed above, this calls for a view of digital infrastructure that integrates perspectives and scalar appreciations from different analytical angles. For example, starting from an international, rather than urban, angle, political scientists have depicted the politics of "large technical systems" underpinning much of the dynamics of "planetary urbanisation" (Brenner 2013; Mayer and Acuto 2015). To address this challenge, for instance, Herrera (2002) discusses the international 'politics of bandwidth' of internet provision in major urbanised areas as a "three-way political struggle between centralized political authorities (states), centralized economic entities (firms) and individuals as both consumers and citizens." In this sense, a better appreciation of the multi-scalar governance of digital infrastructures in the city is but a first, and yet critical, step towards an even broader consideration of the impact of urbanizing digital infrastructures on a complex urban world. Certainly, we can expect the relationships between urban governance and emerging digital infrastructures to remain a complex, yet rapidly evolving territory for urban policy and research for some time to come. 


\section{Acknowledgements: to be added.}

\section{References}

ABC News (2016). Telstra's NBN deal raises competition concerns with the ACCC.

11 April 2016. Accessed 20 April 2016 at: http://www.abc.net.au/news/2016-04$\underline{11 / \text { telstra-nbn-agreement-raises-accc-concerns / } 7315660}$

ACIL Tasman (2013), 'City of Melbourne Knowledge Sector study' at https://www.melbourne.vic.gov.au/AboutMelbourne/KnowledgeMelbourne

Agnew, J. (1997). "The dramaturgy of horizons: geographical scale in the 'reconstruction of Italy' by the new Italian political parties, 1992-1995." Political Geography, 16(2), 99-121.

Alizadeh, T. Sipe, N. \& Dodson, J. (2014) "Spatial Planning and High-Speed Broadband: Australia's National Broadband Network and Metropolitan Planning." International Planning Studies, Volume 19, Issue 3-4, Pages 359-378.

Alizadeh, T. \& Shearer, H. (2015): "A snapshot of high-speed broadband responses at local government level in Australia: a marriage between federally funded initiatives and locally driven innovations?". Australian Planner, DOI:10.1080/07293682.2015.1019754.

Arup. 2010. Smart Cities: Transforming the 21st century via the creative use of technology. London, Sydney, San Francisco. Published by Arup, September 2010.

Arup, Livable Cities, UCL, Smart City Expo. 2014. Delivering the Smart City: Governing Cities in the Digital Age. Published by Arup, December 2014.

Barns, S. (2016), 'Mine your data: open data, digital strategies and entrepreneurial governance by code', Urban Geography 37 (4) 554-71. 
Beckert, J. 1999. "Agency, Entrepreneurs, and Institutional Change: The Role of Strategic Choice and Institutionalized Practices" Organization Studies (20:5), pp. 777799.

Bettencourt, L. 2013. The Uses of Big Data in Cities: SFI Working Paper, Santa Fe Institute, September 2013.

Brenner, N. 2010. "A thousand leaves: notes on the geographies of uneven spatial development.” In Keil, R., \& Mahon, R. (Eds.). (2010). Leviathan undone? Vancouver: UBC Press, pp.27-50.

Bright, P. (2011) "How the London riots showed us two sides of social networking", [online] available at: http://arstechnica.com/tech-policy/news/2011/o8/the-twosides-of-social-networking-on-display-in-the-london-riots.ars [accessed 1st June 2015]

Brisbane City Council. 2012. Digital Brisbane: Strategy for a Digitally Driven Economy. Accessed online 15 January 2015 at http://www.brisbanemarketing.com.au/Business/Digital-Brisbane/pages/Digital$\underline{\text { Strategies.aspx }}$

Broadbent, M. Weill, P. and St.Clair, D. 1999. "The Implications of Information Technology Infrastructure for Business Process Redesign" MIS Quarterly (23:2), pp. 159-182.

BSI. (2014) “The Role of Standards in Smart Cities, Issue 2" available at http://www.bsigroup.com/en-GB/smart-cities/ [accessed $1^{\text {st }}$ June 2015.]

Budde, P. (2016). "Australia bucking the trend by increasing copper." Posted April 22 2016 at http://www.buddeblog.com.au/frompaulsdesk/australia-bucking-the-globaltrend-by-increasing-copper/

Business Innovation and Skills (BIS), UK Department of. (2013). Smart Cities: Background Paper. Accessed online 15 January 2015 at 
https://www.gov.uk/government/uploads/system/uploads/attachment_data/file/2 46019/bis-13-1209-smart-cities-background-paper-digital.pdf

Child, J. (1997). "Strategic Choice in the Analysis of Action, Structure, Organizations and Environment: Retrospect and Prospect" Organization Studies (18:1), pp 43-76

City of New York. 2011. Roadmap for the Digital City. Released July 2011. Accessed 15 January 2015 at http://www.mikebloomberg.com/index.cfm?objectid=F994FBA2C29C-7CA2-FBEE94BD47BD91A3

City of Vancouver. 2012. City of Vancouver Digital Strategy. Accessed 15 January 2015 at: http://vancouver.ca/files/cov/City_of_Vancouver_Digital_Strategy.pdf

Committee for Sydney. 2013. \#wethecity: Collaborating to compete in the digital era. Issues Paper 2, August 2013. Accessed online 15 January 2015 at http://www.sydney.org.au/media/uploads/Issue2 2013 04\%20FINAL\%20EMAIL. pdf

Commonwealth of Australia. 2013 Strategic Review of NBN Co, Final Report. Accessed online 1 May at http://www.nbnco.com.au/content/dam/nbnco/documents/NBNCo-Strategic-Review-Report.pdf

Crang, M., \& Graham, S. (2007). Sentient cities ambient intelligence and the politics of urban space. Information, Communication \& Society, 1O(6), 789-817.

DBCDE. 201 1. National Digital Economy Strategy. Canberra: Australian Government, Department of Broadband Communications Digital Economy. Accessed 20 April 2016 at: http://rdanwq.org.au/files/National Digital Economy Strategy.pdf

Dodson, J. 2009. The 'Infrastructure Turn' in Australian Metropolitan Spatial Planning. International Planning Studies, 14: 2, pp.109-123.

Dodson, J. \& Gleeson, B. 2003. New planning governance for regional Sydney: Lessons from other contexts, Australian Planner, 40(1), pp. 32-39. 
Dublin City Council. 2013. Digital Dublin Masterplan. Available online, last accessed 15 January 2015 at http://digitaldublin.ie/masterplan/

Dunleavy, P. 2006. New Public Management is Dead. Long Live Digital Era Governance. In Journal of Public Adminstration Research and Theory. July 2006. 16: 3., pp 467-494.

Dunleavy, P. and Margetts, H. 2013. The second wave of digital-era governance: a quasi-paradigm for government on the Web. Philosophical Transactions A, DOI: 10.1098/rsta.2012.0382 Published 18 February 2013.

Gibbs, D., Krueger, R., \& MacLeod, G. (2013). Grappling with smart city politics in an era of market triumphalism. Urban Studies, 5o(11), 2151-2157.

Gleeson, B., Darbas, T. \& Lawson, S. 2004. Governance, sustainability and recent Australian metropolitan strategies: A socio-theoretic analysis, Urban Policy and Research, 22(4), pp. 345-366.

Goldsmith, S. and Crawford, S. 2014. The Responsive City: Engaging Communities through Data-Smart Governance. New York: Wiley.

Graham, S., and Marvin, S. (2001), Splintering Urbanism: Networked Infrastructures, Technological Mobilities and the Urban Condition. London: Routledge

Hall, M. (2014) 'Australian Cities in no hurry to be Smart'. The Age, October 282014.

Henfridsson and Bygstad (2013) "The Generative Mechanisms of Digital Infrastructure Evolution” MIS Quarterly, (37: 3) pp.896-931.

Herrera, G. L. (2002). “The politics of bandwidth: international political implications of a global digital information network.” Review of International Studies, 28(1), 93-122.

Hollands, R. G. (2008). Will the real smart city please stand up? Intelligent, progressive or entrepreneurial?. City, 12(3), 303-320. 
International Organisation for Standardisation (ISO) 2014. Committee ISO/TC 268 Sustainable Development in Communities: ISO-37210. Accessed 2 June 2015 at iso.org.

Keil, R., \& Mahon, R. (Eds.). (2010). Leviathan undone? Towards a political economy of scale. Vancouver: UBC Press.

Kitchin, R. (2015) 'Making sense of smart cities: addressing present shortcomings', Cambridge Journal of Regions, Economy and Society 8 (1): 131-36.

Luque-Ayala, A. and S.Marvin (2015), Developing a Critical Understanding of Smart Urbanism? Urban Studies, online first: http://usj.sagepub.com/content/early/2015/03/21/0042098015577319

McNeill, D. (2015), 'Global firms and smart technologies: IBM and the reduction of cities', Transactions of the Institute of British Geographers 40 (4): 562-74

Manchester City Council. 2012. Digital Manchester Strategy. October 2012. Accessed online 15 January 2015 at file:///Volumes/Data/Users/sarahbarns/Downloads/DigitalManchester 1_.pdf

Marvin, S., Luque-Ayala, A. \& McFarlane, C. (2015). Smart Urbanism: Utopian Vision or False Dawn? London: Routledge

Mayer, M., and Acuto, M. (2015). “The Global Governance of Large Technical Systems.” Millennium, 43(2), 660-683.

NBN Co. (2010) Corporate Plan 2011-2013. Canberra: NBN. Accessed 20 April 2016.

Nicholls, R. (2014). “Structural Separation, Interconnection and Access.” Australian Journal of Competition and Consumer Law (22): 54-56 
Purcell, K. 2015 Press release.

https://www.melbourne.vic.gov.au/AboutCouncil/MediaReleases/Pages/Melbourn eselectedforIBMSmarterCitiesChallengeGrant.aspx

Queensland Health Payroll System Commission of Inquiry 2013 Report. Published 31 July, by The Honourable Richard N Chesterman

RDA Hume (2013). Digital Hume: A digital strategy for a smart region. Accessed 20 April 2016 at: http://www.rdv.vic.gov.au/regional-development-australia/hume/ict/ict$\underline{\text { strategy-development }}$

RDA Northern Rivers (2013) Northern Rivers Digital Economy Strategy. Accessed 20 April 2016 at:

$\underline{\text { http://rdanorthernrivers.org.au/download/industry_and_economic_development/di }}$ gital-economy/NR\%20Digital\%20Economy\%20Strategy\%20WEB.pdf

RDA Peel (2012) Building the Peel's digital future. Accessed 20 April 2016 at: http://www.rdapeel.org.au/wp-content/uploads/2015/05/Peel-Digital-FuturesStrategy-FINAL.pdf

RDANI (2013) Digital Economy Strategy 2013. Accessed 20 April 2016 at: http://www.rdani.org.au/projects/digital-economy-strategy.php

Robinson, J. (2013). “'Arriving at' urban policies/the urban: traces of elsewhere in making city futures.” In Söderström, O., Randeria, S., Ruedin, D., D'Amato, G., \& Panese, F. eds. Critical Mobilities. Abingdon: Routledge pp. 1-28.

SMART Infrastructure Facility, Activities and Projects website at http://smart.uow.edu.au, University of Woollongong. Accessed 12 June 2015 at http://smart.uow.edu.au.

Söderström, O., Paasche, T., \& Klauser, F. (2014). "Smart cities as corporate storytelling." City, 18(3), 307-320. 
South Australian Government House of Assembly. (2015) Inquiry into the National Broadband Network: Final Report. 88th Report of the Economics and Finance Committee, December 2015.

Telstra. 2014. Telstra Signs revised NBN Definitive Agreements. Accessed 1 May 2016 at http://www.telstra.com.au/abouttelstra/download/document/asxannouncement.pdf? ssSourceSiteId=aboutus

Telstra. 2016.

Tilson, D., Lyytinen, K., and Sorensen, C. 2010. "Digital Infrastructures: The Missing IS Research Agenda." Information Systems Research (21:4), pp 748-759.

Tilson, D., Lyytinen, K., and Sørensen, C. 2010. "Desperately seeking the Infrastructure in IS Research: Conceptualization of "Digital Convergence" as co-evolution of social and technical infrastructures." 43rd Hawaii International Conference on System Sciences, Hawaii

Townsend A M 2013 Smart Cities: Big Data, Civic Hackers, and the Quest for a New Utopia New York, W.W.Norton

Townsend, A. 2015. "Cities of data: Examining the new urban science". Unpublished article as at 15 January 2015 submitted to Public Culture.

Ubaldi, B. 2013. "Open Government Data: Towards Empirical Analysis of Open Government Data Initiatives", OECD Working Papers on Public Governance, No. 22, OECD Publishing. http://dx.doi.org/10.1787/5k46bj4fo3s7-en

Vaast, E. and Walsham, G. 2009. "Trans-Situated Learning: Supporting a Network of Practice with an Information Infrastructure," Information Systems Research (20:4), pp. $547-564$.

Vanolo, A. (2014). "Smartmentality: The Smart City as Disciplinary Strategy." Urban Studies, 51(5), 883-898. 
Wiig, A. 2-15. "IBM's smart city as techno-utopian policy mobility". City, 19(2-3), 258273. 